Accepted Manuscript (AM) of King, R. and Vullnetari, J. (2012) A population on the move: Migration and gender relations in Albania. Cambridge Journal of Regions, Economy and Society 5(2): 207-220 [DOI:10.1.1009933/c/jcrjerse/sr/srssos0404] [accepted o5 March 2012; published April 2012].

\title{
A population suddenly on the move: migration and changing gender relations in Albania
}

\author{
Russell King and Julie Vullnetari
}

\begin{abstract}
Under the harshest communist regime in Europe, emigration from Albania was impossible, and internal migration was tightly controlled. After 1990, everything changed. Twenty years later 1.4 million Albanians, equivalent to half of Albania's resident population, live abroad; internal migration has also taken place on a massive scale. This paper describes these large-scale migrations within the broader setting of 'post-Wall' European mobility, and relates them to the changing context of gender relations in Albania.
\end{abstract}

Keywords: Albania, migration, gender, remittances, development, population change

JEL Classification: J1, J11, J15, J16

[The Version of Record of this manuscript has been published and is available in Cambridge Journal of Regions, Economy and Society; April 2012; DOI: doi:10.1.1009933/c/jcrjerse/sr/srssos0404]. 
Accepted Manuscript (AM) of King, R. and Vullnetari, J. (2012) A population on the move: Migration and gender relations in Albania. Cambridge Journal of Regions, Economy and Society 5(2): 207-220 [DOI:10.1.1009933/c/jcrjerse/sr/srssos0404] [accepted o5 March 2012; published April 2012].

\section{Introduction}

The events of 1989-91 across Eastern Europe heralded a new phase in European migration. The political transformation of the collapse of the communist regimes resulted in - indeed in some ways was triggered by - a transformation in migratory dynamics. Long denied their human right to emigrate to the West, the citizens of the 'post-Wall' countries desired to exercise their new-won freedom to leave. However, Western European countries, worried about the numbers of potential migrants from east of the old Iron Curtain, strengthened their existing barriers to migration especially from countries of perceived high 'migratory pressure' (Bonifazi et al., 2008, p.12). Nevertheless, a complex set of movements ensued, documented in publications over the last twenty years (see, inter alia, Black et al. 2010; Favell and Elrick, 2008; Gorny, 2004; Morokvasic, 2003; Wallace and Stola, 2001). Migrants included refugees, German and Greek 'ethnic repatriates', shuttle or commuter migrants, irregular movers and trafficked persons. Hybrid types of mobility also evolved, reflecting opportunities for cross-border travel, work and trade affected by visa restrictions, and illustrated by such mixed-motive moves as Arbeitstourismus ('work tourism') and Handelstourismus ('trade tourism') (Morawska, 2000, p.4; Morokvasic, 2003, p.118).

Albania was largely ignored. The literature cited above leaves out this southernmost of the former Eastern bloc states. Not (yet) part of the EU, not part of the Former Soviet Union, nor of Former Yugoslavia, Albania's recent political, economic and migration histories followed a separate set of paths, arguably more dramatic than those evident in the other post-communist states.

The first distinctive feature is the extreme nature of the political and economic transformation - a bipolar swing from centralised autarky to free-market neoliberalism. After breaking first with its revisionist neighbour Yugoslavia in 1948 and then with the major ideological powers (and economic supporters) of Russia (in 1961) and China (in 1978), Albania pursued an isolationist path of self-sufficiency based on intense exploitation of the labour force and development of its natural resources - agriculture, hydro-power, oil and minerals, especially chromite. Textile and garment factories, ore processing plants and other manufacturing and petrochemical industries were strategically developed in several towns. Farming was both 
Accepted Manuscript (AM) of King, R. and Vullnetari, J. (2012) A population on the move: Migration and gender relations in Albania. Cambridge Journal of Regions, Economy and Society 5(2): 207-220 [DOI:10.1.1009933/c/jcrjerse/sr/srssos0404] [accepted o5 March 2012; published April 2012].

intensified through land reclamation and irrigation, and extended to the margins by terracing steep hillsides. The workforce included students, intellectuals and urbandwellers for part of the year, organised in cooperatives, state farms and 'volunteer' groups.

This elaborate and highly centralised economic system, already crumbling, was torn apart as the political system collapsed in the early 1990s. Although the communists (the Albanian Party of Labour) won the first pluralist elections in 1991, a year later they were ousted by the newly-created Democratic Party. These were years of extreme economic chaos as practically all the structures of the old regime, including agricultural cooperatives, irrigation systems, rural health centres etc., were swept away by the pent-up anger of the people and the collapse of the centralised state. Deprived of government support, most factories folded. Food was scarce and only a major humanitarian intervention, led by Italy, plus the actions of hundreds of thousands of Albanians themselves, who emigrated, prevented complete collapse.

The scale of this emigration is the second distinctive feature of the Albanian postcommunist transformation (Carletto et al. 2006). By 2010, nearly half the resident population lived abroad. Emigration, above all else, sustained the economic transformation from an autarkic system based on maximal production and minimal consumption to one based on remittance-fuelled consumption but severely reduced indigenous production. Essentially, post-communist Albania has survived largely through the export of a single product - its labour - the revenues from which (remittances and savings) have kept the economy afloat.

Third, the particular geography of Albanian migration differentiates it from other European post-communist flows. Especially in the 1990s, Albanians migrated, in a spontaneous and irregular fashion, almost exclusively to Greece and Italy, the country's closest EU neighbours (King, 2003). Subsequent regularisations in both Greece and Italy turned these undocumented migrants into more settled immigrant populations which, by 2010, reached 600,000 in Greece and 400,000 in Italy (King et al., 2011). In addition to the 1.4 million who now live abroad, rapid urbanisation and peri-urbanisation of the Tirana-Durrës axis has taken place, as a result of internal migration from the rural highlands and declining mono-industrial towns. 
Accepted Manuscript (AM) of King, R. and Vullnetari, J. (2012) A population on the move: Migration and gender relations in Albania. Cambridge Journal of Regions, Economy and Society 5(2): 207-220 [DOI:10.1.1009933/c/jcrjerse/sr/srssos0404] [accepted o5 March 2012; published April 2012].

The fourth distinctive feature of the Albanian transformation is its gendered nature, especially of migration. In her review of 'post-Wall' mobility, Morokvasic (2003) stresses the feminisation of migrations in this new migratory space between East and West, drawing her empirical evidence from Polish 'shuttle migrants' to Germany. The Albanian case is different: male-dominated in its initial phase of irregular migration, with women following later, as wives and dependants.

\section{Gender and migration - key points}

The introduction of a gendered analysis into the study of migration has been a significant epistemological advance in recent decades. After a long period of 'genderblindness' in migration studies, incorporating gender is now fundamental to a full understanding of the 'migrant experience'.

If one of the tendencies of first-wave feminist writings on migration was to overly concentrate on the experiences of women, subsequent analyses have regarded the categories of 'man' and 'woman' as social and cultural constructs continually enacted in relation to each other (Bjerén, 1997). Hondagneu-Sotelo's argument that 'gender organizes migration' (1994, p.3, our emphasis) requires an explicit focus not just on gender relations but on the hegemonic gender regimes within both sending and receiving societies. As Pessar and Mahler (2003) stress, migration is a dynamic and fluid social process containing key sites of change and conflict with strong implications for gendered practices and ideologies. Reviews of the 'feminisation of migration', either at the global scale (Campani, 1995; Castles and Miller, 2009, p.12), or with reference to post-1989 Europe (Erel et al., 2003, pp.9-10; Morokvasic, 2003), tend to stress women's increased agency in our globalised, post-bipolar world. Others oscillate between seeing women as 'victims' of the globalisation of poverty and inequality, and as 'heroes' of survival (Sassen, 2000). Silvey (2004) stresses that scale, place and 'spatial logic' are powerful organising concepts in a feminist geography of migration. This framing is clearly evident, for instance, in the masculinist construction of borders and border-crossing, of travel and roaming, and of 'being seen' in the public sphere, compared to the social construction of women as family- and home-based and as inherently less mobile. For some, the gendered 
Accepted Manuscript (AM) of King, R. and Vullnetari, J. (2012) A population on the move: Migration and gender relations in Albania. Cambridge Journal of Regions, Economy and Society 5(2): 207-220 [DOI:10.1.1009933/c/jcrjerse/sr/srssos0404] [accepted o5 March 2012; published April 2012].

regime of patriarchy inflicts severe curbs on their independent mobility, even to walk alone down the street of their village.

Our main objective in this paper is precisely to examine this reciprocal relationship between migration and gender relations, taking Albania as a case-study. Next, we outline the methods and projects that our research evidence derives from. Then we provide a reinterpretation of the social significance of Albanian migration over the past twenty years. In the main part of the article, we examine the two-way links between migration and gender, drawing on a variety of empirical evidence that we have mainly collected ourselves. We specifically address the way that Albanian migration has been fundamentally shaped by patriarchal family values, as well as by the immigration policies of the destination countries; and the way that emigration has, in turn, reshaped (to some extent) gender relations in Albania. In the final part of the paper we question the future for migration and gender relations in Albania.

\section{Methods and projects}

Our research material comes from four projects. Only one had a specific gender focus (the third one below) but all of them collected data which may be interpreted through a gender lens. All four projects involved mixed methods but had as their core research instrument in-depth interviews with quite large samples of respondents. Interviews were recorded (where participants agreed), transcribed and selectively translated. They were then analysed following a thematic analysis approach, whereby themes were identified after a detailed process of coding, and then related back to the research questions framing the specific study. Data interpretation reflects respondents' understanding of their reality, but is also influenced by the researchers' multidimensional positionality; reflecting on this was an important part of the process. The analysis of material for projects 3 and 4 was aided by qualitative data analysis software, namely Nud*ist and Nvivo.

Here we mainly use interview extracts which have not been used in other publications deriving from these projects. The four projects are:

1. Research on Albanian migration to the UK and its impact on poverty and development in Albania 2002-03 (see King et al., 2003). Interviews were carried 
Accepted Manuscript (AM) of King, R. and Vullnetari, J. (2012) A population on the move: Migration and gender relations in Albania. Cambridge Journal of Regions, Economy and Society 5(2): 207-220 [DOI:10.1.1009933/c/jcrjerse/sr/srssos0404] [accepted o5 March 2012; published April 2012].

out with Albanian migrants in the London area $(\mathrm{n}=26)$ and with remittance-receiving households and some returnees in Albania $(n=46)$.

2. Research on the social integration of Albanian migrants in Italy, 2001-03. The main interview survey comprised 97 Albanian migrants in three Italian cities Rome, Modena and Lecce (see King and Mai, 2008).

3. A project on gender and remittances in Albania, 2007-09. Field methods comprised a face-to-face questionnaire survey of 350 remittance-receiving households in three villages in south-east Albania and 45 in-depth interviews with remittance-sending migrants in the Greek city of Thessaloniki and with some migrant returnees back in the villages (see Vullnetari and King, 2011).

4. The final project, 2010-13, is an oral-history retrospective of everyday life during the communist period, with gender as one of several themes being researched. We have completed half of the field interviews ( 87 to date) which are distributed across several locations - Tirana, Bulqizë (a mining town), Shkodër (the main city of northern Albania) and various rural places. This is our first publication containing material from this project.

\section{Albanian migration - the story so far}

The chronology of Albanian migration - especially the mass departures of the $1990 \mathrm{~s}$ - has been briefly described above (and see King, 2003; Vullnetari, 2007). Here we devote a little more attention to a reinterpretation of the wider causes and social significance of Albanian migration.

The first act of the Albanian migration 'drama' took place in mid-1990, when approximately 5,000 Albanians, frustrated at not being allowed to travel abroad, entered the compounds of several Western embassies in Tirana - an initial symbolic 'migration' on to foreign soil. Most were eventually given refuge in Western European countries. The second act of the drama occurred in March 1991 when almost 26,000 people commandeered boats to cross the Adriatic Sea to southern Italy. Images of these overcrowded ships docking at Brindisi and Bari have become part of the iconography of mass migration in recent times. Meanwhile, a larger-scale but less visible migration was taking place across the southern mountains into Greece, as bands of mostly young men re-trod hill tracks that had been blocked off for decades. 
Accepted Manuscript (AM) of King, R. and Vullnetari, J. (2012) A population on the move: Migration and gender relations in Albania. Cambridge Journal of Regions, Economy and Society 5(2): 207-220 [DOI:10.1.1009933/c/jcrjerse/sr/srssos0404] [accepted o5 March 2012; published April 2012].

Precise counts of these latter migrants are not available, but estimates indicate 200,000-300,000 during the early 1990 .

Emigration continued throughout the 1990s, with two further peaks around 'crisis moments'. The first occurred in 1997, when an elaborate system of pyramid savings schemes, largely fed by migrant remittances, collapsed and financially ruined a large share of Albanian households. The second peak, in 1999, was triggered by the refugee crisis in neighbouring Kosovo: half a million ethnic Albanian Kosovars crossed the northern Albanian border fleeing the forces of Slobodan Milošević. This put enormous strain on the resources of Albania's poorest region, and led to increased emigration as both local Albanians and the Kosovan refugees moved on to Northern European countries, notably the UK.

Migration continued throughout the 2000s, albeit with declining intensity (Azzarri and Carletto, 2009). By 2010, the World Bank reported 1.4 million Albanians abroad, equal to half of the current resident Albanian population (2.8 million according to the provisional results of the 2011 Census). This ratio puts Albania amongst the top emigration countries worldwide (World Bank, 2011, pp. 4, 54). Indeed, given that nearly all of the countries above Albania in the listing are small island states in the Caribbean or the Pacific with longer histories of emigration, the Albanian case, which developed from a migratory tabula rasa in 1990 , is unique. ${ }^{1}$

\section{Interpretation}

Most explanations of mass migration stress economic factors: the need for survival at moments of crisis, but also a more rational-choice calculation of higher wages and more-secure employment elsewhere. The World Bank's report Poverty in Albania, which assessed the causes of emigration based on extensive questionnaire surveys, found that 39 per cent of respondents left due to unemployment, 26 per cent due to economic insecurity, 20 per cent due to low incomes (a total of 85 per cent for economic motives) and the remainder (15 per cent) to secure a better future for their children (De Soto et al., 2002, p. 45). Another large-scale questionnaire study with migrant households (Kule et al. 2002) found similar results: 87 per cent left for primarily economic reasons, the rest for mainly social and political reasons. 
Accepted Manuscript (AM) of King, R. and Vullnetari, J. (2012) A population on the move: Migration and gender relations in Albania. Cambridge Journal of Regions, Economy and Society 5(2): 207-220 [DOI:10.1.1009933/c/jcrjerse/sr/srssos0404] [accepted o5 March 2012; published April 2012].

But economics is not the whole story. First we note that asking respondents to nominate one principal reason for migrating obscures the multiple and often interlocking reasons that lie within the decision-making process. Where migrants, or other family members, are given the chance to fully articulate the range of factors shaping migration decisions, other important perspectives emerge. These have to do with the political, socio-cultural and identificational/ existential dimensions of dissatisfaction with life in Albania, and pessimism over future prospects. Especially for those who left during the 1990s, there was a double disillusionment - with the rejected communist past of 'shared poverty' and subjugation to 'the regime'; and with the post-communist uncertainties involving economic chaos and an unchanging paternalistic political style. ${ }^{2}$

Interview data reflect both the refugee motive of escaping a repressive political system where punishment and exile were commonplace (the first quote below) and the ongoing political violence of the post-communist era, especially the events of 1997 (the second quote). First we hear from Bilbil (a pseudonym), now late-middle-aged and living in Tirana, but originally from a southern border village. Bilbil's family had tried unsuccessfully to escape to Greece in the 1960s.

I was imprisoned at the age of 16 for six years as a political prisoner... my father was also put in prison... and later we were all, as a family, exiled... to a mountain village far from the border. In 1985 we were released [from exile] but they [the authorities] didn't let us return to our village because it was in a border zone. They sent us to another village instead, and we stayed there until 1995.

Having lived in Greece for a while, Bilbil decided to return and settle with his family in Tirana. His migratory trajectory reflects a common pattern in Albania whereby rural-origin men migrate to Greece for a few years, or go back and forth as seasonal migrants, and then use the capital acquired through migration abroad to support a family resettlement in the capital or another large town (Vullnetari 2008).

The second case presents a different migration pathway - from northern Albania to London. The speaker is a woman in her early 30s, interviewed in London in 2002: 
Accepted Manuscript (AM) of King, R. and Vullnetari, J. (2012) A population on the move: Migration and gender relations in Albania. Cambridge Journal of Regions, Economy and Society 5(2): 207-220 [DOI:10.1.1009933/c/jcrjerse/sr/srssos0404] [accepted o5 March 2012; published April 2012].

We left Albania mainly for political reasons. My husband lost his job because of the political changes. We had a private business... but young people asking for money kept threatening us. The situation in Albania was dangerous and unstable in that period. The police were also asking for money to protect you. The arms stores were open and we were all at risk of being killed.

Beyond the 1997 crisis, threats and intimidation have continued to characterise the Albanian political scene. There is a widespread macho culture of corruption which frustrates attempts at civil-society progress and discourages return migration (Maroukis, 2005). We revisit these issues in the conclusion.

The cultural and existential aspects of Albanian migration motivation were explored in the research carried out for Project 2 by King and Mai (2008), which also builds on Mai's doctoral thesis (Mai, 2002). This line of analysis lays particular emphasis on the role of Italian television in 'disembedding' Albanian young people from their (rejected) social background in Albania. Albanian young people argued that they could only 'find themselves' and 'be the person they wanted to be' by moving abroad. 3 This migratory self-realisation project was directed mainly to Italy, as Italian TV had been secretly watched during the later communist years and then dominated the Albanian mediascape in the post-communist years. For Albanian youth living through the cultural monotony of the communist and immediate postcommunist years, Italian TV, with its spectacularised images of wealth, fun, consumerism and sexuality, offered a dramatically different, and seductive, model of personhood. One word summed up Albanians' impressions of Italy and the Italian way of life - bellissima, beautiful (Mai, 2001a, 2002; King and Mai 2008; pp. 53-61). The following quote exemplifies not only the perceived beauty of Italy but also illustrates a belief among young Albanians that only in Italy (or elsewhere abroad) was it possible to lead a 'normal' life, free of the boredom, family and gender oppression, and propaganda politics of Albania:

The most typical aspect of Albanian TV was monotony and propaganda, whereas Italian TV was characterised by new things, beautiful things... interesting, attractive... beautiful [...] We were looking for something that we 
Accepted Manuscript (AM) of King, R. and Vullnetari, J. (2012) A population on the move: Migration and gender relations in Albania. Cambridge Journal of Regions, Economy and Society 5(2): 207-220 [DOI:10.1.1009933/c/jcrjerse/sr/srssos0404] [accepted o5 March 2012; published April 2012].

could not find at all on Albanian TV... more entertainment, more things to develop our interests... On foreign TV we found programmes that were made expressly for our interests... these did not exist on Albanian TV (Esmerelda, 23, Durrës, 1999).

Later, as Albanians watched Italian TV with a more critical gaze, and as some returned home after having confronted the racist 'albanophobia' in Italy (and in Greece), 4 the migratory destinations widened, mainly to Northern Europe and North America.

\section{Albanian migration 'matures'}

King et al. (2011) and Nikas and Aspasios (2011) draw a distinction between the nature of Albanian migration during the first migration decade of the 1990 s and the second decade, the 2000s. During the 1990s, migration was spontaneous, unplanned, largely irregular, and dominated by young and early-middle-age men. Given that the main migration destinations - Italy and Greece - had no adequate policies for their reception and integration, migrants were only able to access marginal low-paid jobs, typically in agriculture and construction.

Key events marking the passage from the first to the second migration decade were the regularisation schemes launched by the Italian and the Greek governments in the late 1990 s and early 2000s, which enabled most Albanian migrants (and other nationalities) to legalise their stay. This allowed the overall migratory phenomenon to 'mature' in a number of ways. First, it boosted migrants' psychological state: they were no longer in constant fear of being arrested and deported, although problems with 'papers' - especially in Greece - continue to cause considerable stress. Second, it enabled them to access better paid employment although still mainly in the lower echelons of the labour market. Third, and most importantly, it allowed them to bring in wives and children, leading to the formation of an Albanian second generation. With family migration there is a stronger predisposition to long-term settlement in a host society, based on a strategy of building a family-based future, with children passing into the education system abroad. This more settled mode of integration and 
Accepted Manuscript (AM) of King, R. and Vullnetari, J. (2012) A population on the move: Migration and gender relations in Albania. Cambridge Journal of Regions, Economy and Society 5(2): 207-220 [DOI:10.1.1009933/c/jcrjerse/sr/srssos0404] [accepted o5 March 2012; published April 2012].

longer experience of living and working abroad potentially allows a modification of 'traditional' gender roles and relations - our focus in the rest of this paper.

\section{Gender in Albania}

Albania falls within the wider realm of 'Balkan patriarchy' (Kaser, 1996, p. 383) and possibly represents, especially in northern mountainous areas, its most extreme form. Conventionally, but also stereotypically, this is said to result from ordering virtually all aspects of life - especially those on family, 'honour', and gender relations - according to the unwritten rules of the kanun ('canon'), first formulated in the fifteenth century. A detailed discussion of the kanun is beyond our scope here; suffice it to say that it has been too-easily used as a kind of master-trope to 'explain' Albania's alleged proneness to violence and blood-feud killings, and marginalisation of women. 5

It is clear, however, that 'traditional' Albanian society was based on two fundamental tenets: the central function of the family unit, and strong patriarchal principles, involving both patrilinearity (family membership follows the male line) and patrilocality (wives move into the family and the house of the husband's father). Positions and social roles within the family and wider society are ascribed according to gender, generation and age. Women are subordinated within the context of a maledominated 'protective' family, with the oldest men at its apex. Four and a half decades of communism did much to change gender relations. The 1946 constitution gave unprecedented rights for women in a 'traditional' society (Gjonça et al., 2008). Major strides towards equality were made in education, employment and public life. To take just one indicator: at the end of the Second World War more than 90 per cent of women were illiterate and girls were only 3 per cent of secondary-school pupils. By 1989, at the close of the communist era, female illiteracy was 8 per cent and women more than half of all university students (Gjonça et al., 2008; Tarifa, 1992). Nonetheless, women continued to be hard-pressed: 'at home... [having] complete responsibility for child-care and housework while men contributed much less; and at work... [being] expected to contribute as much time and effort as men' (INSTAT, 2004, p. 21). Despite the official policy of gender equality, gender relations remained unequal in the one sphere which 'the Party' could not fully control, the home. 
Accepted Manuscript (AM) of King, R. and Vullnetari, J. (2012) A population on the move: Migration and gender relations in Albania. Cambridge Journal of Regions, Economy and Society 5(2): 207-220 [DOI:10.1.1009933/c/jcrjerse/sr/srssos0404] [accepted o5 March 2012; published April 2012].

Two interview extracts below (from project 4) illustrate these dynamics. The informants live in the far north of Albania, close to the Montenegrin border. First, Mirash (male, 55) talks about child-raising:

No, here [in this region] men have been little involved with children... Men did all the other jobs, but never taking care of the children [...] I am talking about 50 years ago... the law of the kanun... said that it is a [source of] shame for the men to do the caring of the children when there is a woman in the house. In that time for instance, if the man wanted to rock the cradle where his child lay sleeping he would do it when no one was around to see him.

Second, Mri (female, 64) expands on the triple burden women had to shoulder in those days - required to work by 'the regime' but also expected according to the patriarchal rules of society to do all the home-related and child-rearing tasks. Comparing 'then' with 'now', not much has changed, it seems.

To be honest, women have suffered a lot... But men never acknowledge women's contribution. What have you done, they say, you only have these small things in the home to do. Not only then, but also now, women have more work than men, much more. We have sheep, pigs, the cow... all these to take care of, and then we have to do the work inside the house [...] Even immediately after childbirth... we would rush to do the housework.

Not only did patriarchy outlive communism, but it was even strengthened in the power vacuum accompanying the regime's collapse. Some practices harked back to the pre-communist past (e.g. blood feuds and land disputes), others - such as the trafficking of girls for sexual exploitation - were new (Mai, 2001b). Thus, a series of sometimes contradictory trends appeared. On the one hand, the concept of women's emancipation was stigmatised by its association with the discredited communist past, which was seen as having sought to destroy the family. This led to highly oppositional gender roles vis-à-vis the public and private spheres (Nixon 2006, 2009). The public political and economic sphere became increasingly the domain of men, where they 
Accepted Manuscript (AM) of King, R. and Vullnetari, J. (2012) A population on the move: Migration and gender relations in Albania. Cambridge Journal of Regions, Economy and Society 5(2): 207-220 [DOI:10.1.1009933/c/jcrjerse/sr/srssos0404] [accepted o5 March 2012; published April 2012].

could exhibit manliness, decisiveness and profit-seeking behaviour, while femininity was increasingly associated with domesticity, caring and child-rearing. On the other hand, the post-communist urban labour market offered new opportunities for women, such as in the expanding NGO sector and other service-related jobs. This benefited a new generation of well-educated young women, who were increasingly outperforming males at upper-school and university. But other women - of a lower educational and class background - lost out badly with the closure of state farms and factories. Rural women have become one of the most disadvantaged groups, as they have few off-farm employment options. In contrast to earlier decades, the 1990 os saw a decline in women's participation in the labour market and public life. Thus, the female activity rate dropped from 80 per cent in 1989 to 51 per cent by $2002,{ }^{6}$ and the fraction of female parliamentarians fell from around 30 per cent to 6 per cent (UNDP, 2005, pp. 66-7, 75).

\section{Intertwining migration and gender}

Albanian migration as a gendered process

It is a truism of migration studies - but rarely emphasised - that migrations are shaped by the social, gender and class dynamics of migrants' origin countries. Reflecting the patriarchal nature of Albanian society, emigration has been a maledominated process while independent female migration abroad has been limited. The two main exceptions are professional women and students moving to obtain a highstatus qualification or job which brings prestige to the family.

Given that few legal opportunities existed for Albanians to leave their country in the 1990s, emigration was constructed as an inherently dangerous physical act, requiring strength and endurance. It fitted an older, pre-communist notion of migration (kurbet, or 'travel-for-work') as a 'heroic' masculine project in which 'the man' provided for his family by going out in the wider world, thus becoming 'more of a man' through his sacrifice, sweat and blood (King and Vullnetari, 2003, pp. 17-23). In the 'modern' form of kurbet, the sweat is the product of the labouring Albanian body, working on farms or construction sites in Greece and Italy under the hot sun, the blood shed as a result of brutalising by police and border guards (Papailias, 2003). 
Accepted Manuscript (AM) of King, R. and Vullnetari, J. (2012) A population on the move: Migration and gender relations in Albania. Cambridge Journal of Regions, Economy and Society 5(2): 207-220 [DOI:10.1.1009933/c/jcrjerse/sr/srssos0404] [accepted o5 March 2012; published April 2012].

As Papailias argues, the return of kurbet to the Albanian family appears part of a broader process by which 'traditional' gendered divisions of labour are reinstated after the 'aberrant' interlude of communist social engineering. However, equal attention needs to be paid to the contemporary transformations of gendered work identities in post-Fordist Greece and Italy. Here farmers, factory owners, construction bosses, and households looking for cheap domestic help and care assistance have been only too willing to incorporate Albanian migrants into rejected, gendered niches in their informal economies (Papailias, 2003, pp. 1064-7).

There is, however, a danger of writing women completely out of the early years of Albanian migration. In the images of overcrowded ships docking in southern Italy in 1991, it was difficult to identify any women, and the journalistic and field accounts of bands of migrants trekking over the mountains to Greece speak of the (exclusively male) migrants having almost superhuman qualities (King et al., 1998). But our own extensive interview records show that some women did make those arduous journeys, walking for days on end, risking their lives on smugglers' speedboats, stowing away in the backs of lorries (for the trip across the Channel to the UK), usually accompanied by close male relatives.

Host-country figures for Albanian migrants reveal that women were, indeed, in a minority in the early years (around 18-25 per cent in Greece and Italy in the earlymid 1990s), but rose rapidly to 40 per cent of the total in the Greek and Italian censuses of 2001 (King and Mai, 2008, pp. 88-9, 96). Regularisation, family reunification and the birth of children are the key elements in this process of demographic 'normalisation'. This progressed one step further in the last decade as some of the older generation -migrants' parents - moved to Greece or Italy to look after their grandchildren so that both the original migrant and his wife could undertake paid work (King and Vullnetari, 2006).

This evolution of Albanian migration has changed the nature of transnational relations between migrants and Albania. This is clearly seen in the way that remittances - the economic raison d'être of labour migration - are channelled back to non-migrant family members. Based on recent research on 'gendering remittances' (Project 3: King and Vullnetari, 2010; Vullnetari and King, 2011), we identify three main types of transnational household: 
Accepted Manuscript (AM) of King, R. and Vullnetari, J. (2012) A population on the move: Migration and gender relations in Albania. Cambridge Journal of Regions, Economy and Society 5(2): 207-220 [DOI:10.1.1009933/c/jcrjerse/sr/srssos0404] [accepted o5 March 2012; published April 2012].

- an extended multi-generation family in rural Albania, one or more members of which (nearly always sons) works abroad and sends remittances to the head of the family (the oldest male);

- a nuclear family (wife and children) living in Albania, with the husband abroad and sending remittances to his wife;

- older parents whose adult sons and daughters all live away - remittances are usually sent by sons and received by fathers.

These formations are structured by 'traditional' norms of gender and generation. For instance, where the 'emigrant unit' is the nuclear family, remittances are usually sent only to the husband's parents, not the wife's (since the wife 'belongs' to the husband's family, and it is the responsibility of her brothers to support her parents). Women are rarely 'allowed' to send remittances, since they are not regarded as independent economic agents. Back in Albania, women only receive remittances if their husbands are abroad and they are, pro tem, the head of the residual family unit; or when, amongst the older generation, they are widows or their husbands are sick or otherwise incapable. Where, however, 'residual wives' are living (with their children) with their in-laws in an extended patrilocal household, remittances from the husband are sent to the father as the household head.

Yet migration is itself a transformatory event - as noted earlier, it is a site of change with strong implications for gender roles and practices (Pessar and Mahler, 2003; Silvey, 2004). It generally takes place at a key stage in the life-cycle, such as the transition to adulthood or the formation of a family, and it embodies movement from one society to another. In the next section we assess the extent to which it has been an empowering experience for Albanian women.

\section{Migration and empowerment: achievement versus delusion}

Evidence here is mixed. Much depends on time and place. Studies of migration and remittances based on north Albania and migration flows from here to the London region (Project 1) generally reveal rather conservative patterns, reflecting the 'traditional' nature of northern Albanian society (Dalipaj, 2005; King et al., 2003, 2006). Patriarchal relations are found to be intact, structuring the migration and 
Accepted Manuscript (AM) of King, R. and Vullnetari, J. (2012) A population on the move: Migration and gender relations in Albania. Cambridge Journal of Regions, Economy and Society 5(2): 207-220 [DOI:10.1.1009933/c/jcrjerse/sr/srssos0404] [accepted o5 March 2012; published April 2012].

settlement process, and governing the sending and receiving of remittances. Moreover, different migration pathways are often entwined within the same family, with children in different countries, as well as internal migration between the rural hinterland and the Albanian capital. This quote, from an elderly household head now living in Kamza, a sprawling peri-urban area near Tirana airport, sums up these complex trajectories and stages.

We used to live in Burrel [north-central Albania]. When democracy arrived, we all lost our jobs there and families started moving down here bit by bit. First the young men went, then the rest of the family followed. This is what we did; we sold everything and came down here... The first floor of this house was built by selling the place in Burrel. The second and third floors were built thanks to the money my two grandsons sent from the UK... It was expensive to send them there [referring to smugglers' fees etc.]... we borrowed some money, and all of the money my sons had saved from Greece.

Note, however, that the interviewee speaks only of the male family members; women are absent from his account. This is a subtle rendering of the persistence of patriarchy, worded more strongly in other quotes as in the one below:

The head of the household makes the decision... we can't change his mind on anything. He is like Enver [Hoxha]. People have to live in a strong regime, that's the only way... The sons listen to their father, all my children listen only to him... they respect the tradition (woman, mid-5os, northern Albania, 2003).

Yet this survival of patriarchy is being modified even in the north of Albania (King et al., 2006), but especially in migration streams originating in the less-traditional south and in urban areas. This is illustrated in more recent work in Fier, south of Tirana (Smith, 2009) and by our own research on gendering remittances in rural south-east Albania (Vullnetari and King, 2011). We observed, first, a greater sharing of receiving and managing remittances, in acknowledgement that wives and mothers take care of the household economy. 'She holds the purse' is the common phrase to 
Accepted Manuscript (AM) of King, R. and Vullnetari, J. (2012) A population on the move: Migration and gender relations in Albania. Cambridge Journal of Regions, Economy and Society 5(2): 207-220 [DOI:10.1.1009933/c/jcrjerse/sr/srssos0404] [accepted o5 March 2012; published April 2012].

capture this. Second, more migrant women send remittances to their parents, instead of having their surplus earnings 'captured' by their husbands and sent to his parents, according to the patriarchal model.

Irena, 37, lives in Thessaloniki with her husband and two children. As a family, it is understood that supporting their parents comes second. But they try to give small amounts, described as 'presents' or 'just for a coffee', to both sets of parents. Moreover, when Irena makes gifts to her own parents she makes a point of treating them equally:

It's usually mothers who collect the money; my mother in our family. But when I send the money, I send $€ 10$ for my father and $€ 10$ to my mother so that both are happy, because they are old now... And father goes to mother and gives her the money... he knows: what is she going to do with it? They have spent a whole life managing together. She won't go out and spend it on having coffee. They will have their coffee together at home.

Usually the female-to-female (in this case daughter to mother) transmission of remittances is sanctioned by male relatives (husbands, fathers etc.). However, Smith (2009) uncovered evidence of more-secretive channels of remittances sent between women, put into practice as a form of resistance against masculine power and as an act of solidarity between female kin members, including sisters. Other interviewees made a distinction between receiving/ administering the money and deciding on how it is spent:

Mother is the one I give the money to, of course... Because mothers are the ones who usually have this task [of administering the money]... When it comes to deciding how it will be used, it is father who decides (Besmir, male, 24, Thessaloniki, 2008).

Not all female remittance recipients welcomed the responsibility involved, especially when their husbands were abroad, leaving their wives with sole responsibility for managing the household, bringing up the children, and perhaps 
Accepted Manuscript (AM) of King, R. and Vullnetari, J. (2012) A population on the move: Migration and gender relations in Albania. Cambridge Journal of Regions, Economy and Society 5(2): 207-220 [DOI:10.1.1009933/c/jcrjerse/sr/srssos0404] [accepted o5 March 2012; published April 2012].

also working the land or looking after livestock. Donika (37) lives in a village with her four children, whilst her husband is a migrant in Greece:

If he is here [in Albania] it goes without saying that he has that responsibility [of decision-making], he takes that from the day he arrives... [then] I feel more relaxed. When he is not here, I am on my own... I am the one bearing the burden in the family.

Two more facets of the gender-migration relationship deserve attention: life abroad and return migration.

Moving abroad, not only to a different society but also to a different social situation (that of the 'migrant worker' or the 'immigrant family'), inevitably poses a challenge to established gender relations. Although the nuclear family has now become the most typical migrant unit for Albanians, there are still cases of male-only households, generally composed of relatives (brothers, cousins) and friends (covillagers) who live together in a shared flat or cottage. This form of single-sex household barely exists in Albania. Yet, over the years in Greece and Italy, it has given male migrants 'training' in household management, especially cooking and cleaning skills.

Our fieldwork amongst Albanian families in Thessaloniki (Vullnetari and King, 2011) documented the ways in which husbands and wives had moved to a more egalitarian sharing of household tasks such as childcare, food preparation and shopping. Often this was guided primarily by the logistical necessity of arranging responsibilities when both parents were working full-time, possibly on different timeshifts. Just as male migrants might pick children up from school and prepare their meals, so migrant wives would travel freely by car or public transport across town to work or meet friends in cafés or bars.

Return brings another confrontation with gender relations - to a certain extent a return to the status quo ante. Culturally and socially, life remains stifling in rural areas, especially for young women; they are rarely seen in the street after dark, especially without a close male family member. Preserving the 'honour' of the family remains paramount. Surveillance of behaviour is performed by women themselves as 
Accepted Manuscript (AM) of King, R. and Vullnetari, J. (2012) A population on the move: Migration and gender relations in Albania. Cambridge Journal of Regions, Economy and Society 5(2): 207-220 [DOI:10.1.1009933/c/jcrjerse/sr/srssos0404] [accepted o5 March 2012; published April 2012].

much as by men. One of our female respondents, a married woman who had been used to travelling independently around Thessaloniki in the normal course of her work and social life, was disappointed to find, on a return visit to her village in Albania, that her visits on her own to the local town, Korçë, were commented on pointedly by her neighbours. She had remained in the village after her husband had returned to Greece, and needed to clear up some bureaucratic affairs in town. Her neighbours in the village assumed she must be up to no good.

\section{Conclusion}

As post-communism enters its third decade, migration from Albania continues but in a less desperate and more measured fashion. The peak of emigration has passed. Remittances are falling year-on-year, partly provoked by the economic crisis and partly due to the 'maturing' of the settlement and integration process described earlier. Internal migration will continue to drain people, especially the young, from peripheral regions, as education and employment opportunities draw them to Tirana and other university towns such as Shkodër, Durrës and Korçë. However, internal migration, despite its massive scale, is the under-researched side of Albanian migration, and there are very few studies which deal specifically with how gender relations are affected by moves from the countryside to the city. It also needs to be pointed out that internal and international migration is often interwoven within the same family in complex ways. A common pattern is for short-term emigration to Greece to be used as a means of financing the move of the family base from the village to the city (Vullnetari, 2008). Here too, more research is needed.

A question-mark hangs over return migration. The settling-down of sizeable migrant communities in Greece, Italy, the UK and the US would seem to rule out return migration, at least for the time being. But thoughts of return, if not an actual yearning, seem intrinsic to the migrant condition. There are no statistics on return, but a number of studies have shown that return is taking place (Labrianidis and Hatziprokopiou, 2005; Labrianidis and Kazazi, 2006), and in some areas it seems that small businesses, such as shops and garages, are run by return migrants who have used their savings from working abroad to start small enterprises (Nicholson, 2001, 2004). The severity of the Greek economic crisis has hit many Albanian 
Accepted Manuscript (AM) of King, R. and Vullnetari, J. (2012) A population on the move: Migration and gender relations in Albania. Cambridge Journal of Regions, Economy and Society 5(2): 207-220 [DOI:10.1.1009933/c/jcrjerse/sr/srssos0404] [accepted o5 March 2012; published April 2012].

migrants hard, with reduced incomes and work opportunities, and press reports in both countries speak of migrants 'giving up' and moving back to Albania, but this seems to be a trickle rather than a flood. Return is unlikely to take place on a large scale for two principal reasons. First, as migration matures into family settlement abroad, there is a need to sustain family incomes and to build an educational and career future for children which would be interrupted were return to take place. Second, the Albanian economic environment is not propitious for employmentseeking or business-minded returnees. Wages are low, jobs are scarce, the infrastructure (especially power and water supplies) is deficient, and the sociopolitical environment is still blighted by corruption and trickery. According to Maroukis (2005), this last factor is one of the main obstacles to a more positive interaction between return migration and development.

One of the key dimensions of an improved civil society is gender relations. This aspect of social change is in continuous evolution and also subject to great contrast, especially between rural and urban areas. Smart-casual young women strolling the boulevards of Tirana or Shkodër might be from any European city, but things are different behind closed doors, and very different in the villages and decaying industrial towns of the interior, where traditional patriarchy survives and thrives. As we have shown, emigration was initially a 'male' act, with women only following as wives and daughters. Subsequently the experience of migration restructures gender roles and relations, but only up to a point, and much of this empowerment is lost if return migration occurs.

Little encouragement towards gender equality comes from 'the top' in Albania. One of the ironies of gender equality during communist times was the concentration of autocratic power in the hands of one man, Enver Hoxha, father and protector of the nation. It is not difficult to see the continuation of the paternalistic, hectoring style of macho leadership in the post-communist political landscape, notably embodied in the behaviour of Sali Berisha who, as a former communist and now leader of the Democratic Party, has dominated Albanian politics for more than twenty years. Meanwhile, the flourishing of formal civil society organisations is encouraging, but their absence in rural areas, especially of women's groups, is also a reflection of the fact that so much needs to be done. 
Accepted Manuscript (AM) of King, R. and Vullnetari, J. (2012) A population on the move: Migration and gender relations in Albania. Cambridge Journal of Regions, Economy and Society 5(2): 207-220 [DOI:10.1.1009933/c/jcrjerse/sr/srssos0404] [accepted o5 March 2012; published April 2012].

\section{Acknowledgment}

We would like to thank Oxfam GB, the Leverhulme Trust, UN-INSTRAW (United Nations International Research and Training Institute for the Advancement of Women) and UNDP (United Nations Development Programme) for funding the research that this paper draws on. Many thanks also to two anonymous referees for their comments and suggestions on earlier drafts.

\section{Notes}

1 From an East European post-communist perspective, other noteworthy cases are Bosnia-Herzegovina, where the emigrant stock is equivalent to 38.9 per cent of the resident population, Macedonia (21.9 per cent), and Moldova (21.5 per cent). For the full list see World Bank (2011, p. 4).

2 Despite the switch to democracy after 1990, this break with the authoritarian collectivised past was less marked in Albania than in many other former communist states. Both main parties - the Democrats and the Socialists - have perpetuated the tradition of personalistic, male authoritarian rule pioneered by Enver Hoxha.

3 This diagnosis is relevant for Albania's first post-communist decade. Nowadays, however, many Albanian young people, particularly in urban areas, are more self-confident about developing their lives and careers in Albania. Apart from those who go abroad for professional reasons - for instance for postgraduate training - there is more a view that those who are 'forced' to emigrate are the poorer, more disadvantaged classes.

4 There is widespread research on Albanians' experiences of life, work and racism in Italy and Greece; see King and Mai (2008, 2009) on Italy, and Hatziprokopiou (2003) and Lazaridis and Koumandraki (2007) on Greece.

5 The north Albanian kanun, ascribed to highland chieftain Lekë Dukagini, is the most notorious in its patriarchal and blood-line principles, but there are other kanuns which have operated in other regions of Albania. Typical of the difficulty of an objective analysis of the contemporary significance of the kanun is Schwandner-Sievers' suspicion of it being reactivated and 'performed' in 
Accepted Manuscript (AM) of King, R. and Vullnetari, J. (2012) A population on the move: Migration and gender relations in Albania. Cambridge Journal of Regions, Economy and Society 5(2): 207-220 [DOI:10.1.1009933/c/jcrjerse/sr/srssos0404] [accepted o5 March 2012; published April 2012].

northern Albania for the benefit of visiting anthropologists! (2004, p. 115). See also de Waal (2005, pp. 83-94).

6 Partly this was due to the fact that women were no longer forced to work in the state-managed economy, but another factor to be borne in mind was the closure of state childcare facilities.

\section{References}

Azzarri, C. and Carletto, G. 2009. Modelling migration dynamics in Albania: a hazard function approach, Southeast European and Black Sea Studies, vol. 9, no. 4, pp. 407-33.

Bjerén, G. 1997. Gender and reproduction, in T. Hammar, G. Brochmann, K. Tamas and T. Faist (eds) International Migration, Immobility and Development: Multidisciplinary Perspectives. Oxford, Berg, pp. 219-46.

Black, R., Engbersen, G., Okólski, M. and Pantiru, C. (eds) 2010. A Continent Moving West?: EU Enlargement and Labour Migration from Central and Eastern Europe. Amsterdam, Amsterdam University Press.

Bonifazi, C., Okólski, M., Schoorl, J. and Simon, P. (eds) 2008. International Migration in Europe: New Trends and New Methods of Analysis. Amsterdam, Amsterdam University Press.

Campani, G. 1995. Women migrants: from marginal subjects to social actors, in R. Cohen (ed.) The Cambridge Survey of World Migration. Cambridge, Cambridge University Press, pp. 546-50.

Carletto, G., Davis, B., Stampini, M. and Zezza, A. 2006. A country on the move: international migration in post-communist Albania, International Migration Review, vol. 40, no. 4, pp. 467-85.

Castles, S. and Miller, M.J. 2009. The Age of Migration: International Population Movements in the Modern World. Basingstoke, Palgrave ( $4^{\text {th }}$ edition).

Dalipaj, M. 2005. Albanian Migration to the UK: A Hidden Migration? MPhil thesis in Migration Studies, University of Sussex. 
Accepted Manuscript (AM) of King, R. and Vullnetari, J. (2012) A population on the move: Migration and gender relations in Albania. Cambridge Journal of Regions, Economy and Society 5(2): 207-220 [DOI:10.1.1009933/c/jcrjerse/sr/srssos0404] [accepted o5 March 2012; published April 2012].

De Soto, H., Gordon, P., Gedeshi, I. and Sinoimeri, Z. 2002. Poverty in Albania: A Qualitative Assessment. Washington DC, World Bank Technical Paper 520.

de Waal, C. 2005. Albania Today: A Portrait of Post-Communist Turbulence. London, IB Tauris.

Erel, U., Morokvasic, M. and Shinozaki, K. 2003. Bringing gender into migration, in M. Morokvasic, U. Erel, and K. Shinozaki (eds) Crossing Borders and Shifting Boundaries: Gender on the Move. Opladen, Leske + Budrich, pp. 9-22.

Favell, A. and Elrick, T. (eds) 2008. The New Face of East-West Migration in Europe. Special Issue, Journal of Ethnic and Migration Studies, vol. 34, n. 5, pp. 701-841.

Gjonça, A., Aassve, A. and Mencarini, L. 2008. Albania: trends and patterns, proximate determinants and policies of fertility change, Demographic Research, vol. 19, no. 2, pp. 261-92.

Gorny, A. (ed.) 2004. Migration and the New Europe: East-West Revisited. Basingstoke, Palgrave.

Hatziprokopiou, P. 2003. Albanian immigrants in Thessaloniki, Greece: processes of economic and social incorporation, Journal of Ethnic and Migration Studies, vol. 29, no. 6, pp. 1033-57.

Hondagneu-Sotelo, P. 1994. Gendered Transitions: Mexican Experiences of Immigration. Berkeley, University of California Press.

INSTAT. 2004. Gender Perspectives in Albania. Tirana, INSTAT.

Kaser, K. 1996. Introduction: household and family contexts in the Balkans, History of the Family, vol. 1, no. 4, pp. 375-86.

King, R. 2003. Across the sea and over the mountains: documenting Albanian migration, Scottish Geographical Journal, vol. 119, no. 3, pp. 283-309.

King, R. and Mai, N. 2008. Out of Albania. Oxford, Berghahn.

King, R. and Mai, N. 2009. Italophilia meets Albanophobia: paradoxes of asymmetric assimilation and identity among Albanian immigrants in Italy, Ethnic and Racial Studies, vol. 32, no. 1, pp. 117-38. 
Accepted Manuscript (AM) of King, R. and Vullnetari, J. (2012) A population on the move: Migration and gender relations in Albania. Cambridge Journal of Regions, Economy and Society 5(2): 207-220 [DOI:10.1.1009933/c/jcrjerse/sr/srssos0404] [accepted o5 March 2012; published April 2012].

King, R. and Vullnetari, J. 2003. Migration and Development in Albania. Development Research Centre on Migration, Globalisation and Poverty, Working Paper C5, University of Sussex.

King, R. and Vullnetari, J. 2006. Orphan pensioners and migrating grandparents: the impact of mass migration on older people in rural Albania, Ageing and Society, vol. 26 , no. 5, pp. $783-816$.

King, R. and Vullnetari, J. 2010. Gender and Remittances in Albania: Or Why 'Are Women Better Remitters than Men?' Is Not the Right Question. Sussex Centre for Migration Research, Working Paper 58, University of Sussex.

King, R., Dalipaj, M. and Mai, N. 2006. Gendering migration and remittances: evidence from London and Northern Albania, Population, Space and Place, vol. 12, no. 6, pp. 409-34.

King, R., Iosifides, T. and Myrivili, L. 1998. A migrant's story: from Albania to Athens, Journal of Ethnic and Migration Studies, vol. 24, no. 1, pp. 159-75.

King, R., Mai, N. and Dalipaj, M. 2003. Exploding the Migration Myths. London, The Fabian Society and Oxfam GB.

King, R., Uruçi, E. and Vullnetari, J. 2011. Albanian migration and its effects in comparative perspective, Journal of Balkan and Near Eastern Studies, vol. 13, no. 3, pp. 269-86.

Kule, D, Mançellari, A., Papapanagos, H., Qirici, S. and Sanfey, P. 2002. The causes and consequences of Albanian emigration during transition: evidence from microdata, International Migration Review, vol. 36, no. 1, pp. 229-39.

Labrianidis, L. and Hatziprokopiou, P. 2005. The Albanian migration cycle: migrants tend to return to their country of origin after all, in R. King, N. Mai and S. Schwandner-Sievers (eds) The New Albanian Migration. Brighton, Sussex Academic Press, pp. 93-117.

Labrianidis, L. and Kazazi, B. 2006. Albanian return-migrants from Greece and Italy: their impact on spatial disparities within Albania, European Urban and Regional Studies, vol. 13, no. 1, pp. 59-74. 
Accepted Manuscript (AM) of King, R. and Vullnetari, J. (2012) A population on the move: Migration and gender relations in Albania. Cambridge Journal of Regions, Economy and Society 5(2): 207-220 [DOI:10.1.1009933/c/jcrjerse/sr/srssos0404] [accepted o5 March 2012; published April 2012].

Lazaridis, G. and Koumandraki, M. 2007. Albanian migration to Greece: patterns and processes of inclusion and exclusion in the labour market, European Societies, vol. 9, no. 1, pp. 91-111.

Mai, N. 2001a. 'Italy is beautiful': the role of Italian television in the Albanian migratory flow to Italy, in R. King and N. Wood (eds) Media and Migration: Constructions of Mobility and Difference. London, Routledge, pp. 95-109.

Mai, N. 2001b. Transforming traditions: a critical analysis of the trafficking and exploitation of young Albanian girls in Italy, in R. King (ed.) The Mediterranean Passage: Migration and New Cultural Encounters in Southern Europe. Liverpool, Liverpool University Press, pp. 258-78.

Mai, N. 2002. Between Losing and Finding Oneself: The Role of Italian Television in the Albanian Migration to Italy. DPhil thesis in Media and Cultural Studies, University of Sussex.

Maroukis, T. 2005. Albanian migrants in Greece: transcending 'borders' in development, Journal of Southern Europe and the Balkans, vol. 7, no. 2, pp. 21333 .

Morawska, E. 2000. Transnational Migrations in the Enlarged European Union: A Perspective from East Central Europe. Florence, European University Institute, Working Paper 2000/19.

Morokvasic, M. 2003. Transnational mobility and gender: a view from post-wall Europe, in M. Morokvasic, U. Erel, and K. Shinozaki (eds) Crossing Borders and Shifting Boundaries: Gender on the Move. Opladen, Leske + Budrich, pp. 101133.

Nicholson, B. 2001. From migrant to micro-entrepreneur: do-it-yourself development in Albania, South-East Europe Review, vol. 4, no. 3, pp. 39-42.

Nicholson, B. 2004. The tractor, the shop and the filling-station: work migration and self-help development in Albania, Europe-Asia Studies, vol. 56, no. 6, pp. 877-90. 
Accepted Manuscript (AM) of King, R. and Vullnetari, J. (2012) A population on the move: Migration and gender relations in Albania. Cambridge Journal of Regions, Economy and Society 5(2): 207-220 [DOI:10.1.1009933/c/jcrjerse/sr/srssos0404] [accepted o5 March 2012; published April 2012].

Nikas, C. and Aspasios, D. 2011. The changing characteristics and maturity of Albanian emigration to Greece, Journal of Balkan and Near Eastern Studies, vol. 13, no. 3, pp. 287-301.

Nixon, N. 2006. The absence of gender: Albania's National Strategy on Migration, Albanian Journal of Politics, vol. 2, no. 1, pp. 44-61.

Nixon, N. 2009. 'You can't eat shame with bread': gender and collective shame in Albanian society, Southeast European and Black Sea Studies, vol. 9, no. 1, pp. 105$-21$.

Papailias, P. 2003. 'Money of kurbet is money of blood': the making of a 'hero' of migration at the Greek-Albanian border, Journal of Ethnic and Migration Studies, vol. 29, no. 6, pp. 1059-78.

Pessar, P.R. and Mahler, S.J. 2003. Transnational migration: bringing gender in, International Migration Review, vol. 37, no. 3, pp. 812-46,

Sassen, S. 2000. Countergeographies of globalization and the feminization of survival, Journal of International Affairs, vol. 53, no. 2, pp. 503-24.

Schwandner-Sievers, S. 2004. The enactment of 'tradition': Albanian constructions of identity, violence and power in times of crisis, in B.E. Schmidt and I.W. Schröder (eds) Anthropology of Violence and Conflict. London, Routledge, pp. 97-120.

Silvey, R. 2004. Power, difference and mobility: feminist advances in migration studies. Progress in Human Geography, vol. 28, no. 4, pp. 490-506.

Smith, E. 2009. 'Gap-fillers' or 'clan-destroyers': transnational female solidarity towards kin in the region of Fier, Southeast European and Black Sea Studies, vol. 9, no. 4, pp. 555-73.

Tarifa, F. 1992. The unequal equalities of women's academic careers in Albania, Higher Education in Europe, vol. 17, no. 2, pp. 44-59.

UNDP. 2005. National Human Development Report Albania: Pro-Poor and ProWomen Policies and Development in Albania. Tirana, UNDP Albania. 
Accepted Manuscript (AM) of King, R. and Vullnetari, J. (2012) A population on the move: Migration and gender relations in Albania. Cambridge Journal of Regions, Economy and Society 5(2): 207-220 [DOI:10.1.1009933/c/jcrjerse/sr/srssos0404] [accepted o5 March 2012; published April 2012].

Vullnetari, J. 2007. Albanian Migration and Development: State-of-the Art Review. IMISCOE Working Paper 18, Amsterdam.

Vullnetari, J. 2008. The Dynamics between Internal and International Migration: A Development-Oriented Ethnographic Study in Albania. DPhil thesis in Migration Studies, University of Sussex.

Vullnetari, J. and King, R. 2011. Remittances, Gender and Development: Albania's Society and Economy in Transition. London, IB Tauris.

Wallace, C. and Stola, D. (eds) 2001. Patterns of Migration in Central Europe. Basingstoke, Macmillan.

World Bank. 2011. Migration and Remittances Factbook 2011. Washington DC, World Bank. 